\title{
HORIZONTALIST YOUTH CAMPS AND THE BOLIVARIAN REVOLUTION: A STORY OF BLOCKED DIFFUSION
}

\author{
Lesley J. Wood \\ York University \\ Department of Sociology \\ ljwood@yorku.ca
}

\begin{abstract}
Between 2001 and 2005, the Intercontinental Youth Camp at the World Social Forum in Porto Alegre, Brazil became associated with a decentralized, horizontalist form of organizing. When the polycentric forum took place in 2006, this horizontalist identity and strategy did not diffuse successfully to the new site in Caracas, Venezuela. This article argues that for diffusion to be successful, the local hosts must be able to deliberate on the locally new idea, see themselves as similar to the earlier users, and have the opportunity to adapt the tactic to the local context. Analysing interviews with participants, and activist writing, I argue that the relational context of Caracas, Venezuela, along with recent events in that city, made such processes impossible. In particular, the deliberation essential for diffusion was blocked by the centralization and polarization of the political field, the formalization of the potential adopters, and the temporal proximity of a similar event, the World Festival of Youth and Students.
\end{abstract}

\section{INTRODUCTION}

From their inception at the first World Social Forum (WSF), the Intercontinental Youth Camps (IYC) were sites of organizational experimentation. In particular, the camps in Porto Alegre, Brazil were associated with "horizontalism". Horizontalism is both an identity and a way of organizing and making decisions most recently associated with new anti-capitalist social movements in Argentina, Brazil, and Mexico. Although widely celebrated as an innovation by observers of the World Social Forum process and some participants in the camps in Porto Alegre, this horizontalist identity was not intrinsic to the Intercontinental Youth Camp as an institution. When the IYC left Brazil for India in 2004, and for the polycentric sites of Bamako, Mali, Karachi, Pakistan and Caracas,Venezuela in 2006, the horizontalist identity did not diffuse to the new locales.

This article looks at the diffusion of the horizontalist identity from the Intercontinental Youth Camp at Porto Alegre Brazil in 2005 to the IYC in Caracas the following year. I do this from a distance, as I was not in either Porto Alegre, nor in Caracas. I became interested in the question of how the Venezuelan context influenced the World Social Forum after having informal discussions with activists who had recently returned home from the 2005 World Festival of Youth and Students (WFYS). One Toronto activist told me that she had been told by a member of the 
organizing committee in Caracas, that the World Festival was seen as a 'test-run' for the upcoming World Social Forum. This compelled me to look more closely at how available models for organizing and local contexts influence the evolution of global justice movement convergences such as the WSF. I want to make an argument about the importance of understanding the layers of context in diffusion processes, and how these contexts become important through the ways that they affect internal debates amongst activists. My evidence is not systematic, but I believe it is suggestive. In order to understand how youth camp organizers and participants understood their practices, I looked at the available report-backs by participants from the camps, coverage by journalists about the camps and activist blogs. In these sources, I looked for expressions of, and references to the political identity "horizontalism" that has become associated with the Intercontinental Youth Camps. What I found prompts me to argue that the relational context of Caracas, Venezula, and recent events in that city, blocked the diffusion of the horizontalist identity from Porto Alegre to Caracas by limiting the interest and willingness of local activists to engage in discussions of that identity.

\section{DIFFUSION OF HORIZONTALIST INNOVATION}

While the classic work by Everett Rogers (2003) on diffusion describes the process as one whereby a bounded innovation is transmitted, received and adopted in a linear process, I follow Sean Chabot (2000) and others in arguing that the diffusion of political practices is an ongoing, social process. In my observations on the spread of the horizontalist youth camp identity I use Katz's definition of diffusion because it emphasizes this process in a way that shows its complexity: "Diffusion ... [is] defined as the acceptance of some specific item, over time, by adopting units - individuals, groups, communities - that are linked both to external channels of communication and to each other by means of both a structure of social relations and a system of values, or culture" (1968).

Indeed, I believe that for the incorporation of a new political idea, potential adopters must have an opportunity to engage in deliberation. Deliberative discussions involve conversations amongst relative equals, who offer a diversity of viewpoints, share claims that are backed up by reasoned arguments, and, for some theorists, have some reflexivity about the agenda and the procedures for discussion (Cohen 1989; Dryzek 1990; Fishkin 1991). Such conversations are crucial for allowing potential receivers to be reflexive, strategic, and sustainable about their tactical decision making (Chabot and Duyvendak 2002: 727; Opp and Ruel 1990: 526; Rogers 2003: 429). Through deliberation, potential adopters have an opportunity to abstract an idea or practice from its original setting (Strang \& Meyer 1993: 492). In his study of the African American reinvention of Gandhian non-violence, Chabot (2000) recognized how a tactic becomes transformed through, among other things, the use of intellectual dislocation. Intellectual dislocation is a process of abstracting an idea from its original setting that takes place through deliberation. In this manner, participants in a local social movement field can evaluate a tactic and decide whether to certify the practice as appropriate and useful and thus generate rules and practices for its local use (Tilly 2003a). Incorporation of an innovation into an organization's repertoire amounts to a mutual adaptation of the innovation and the organization (Van de Ven 1986) "Adaptation must occur because the innovation almost never fits perfectly in the organization in which it is to become embedded. Thus, a fair degree of creative activity is 
required to avoid or to overcome the misalignments that occur between the innovation and the organization” (Rogers 2003: 395). Without such activity, a new or revitalized tactic is much less likely to be experimented with in a new context.

Theories of social networks have found that certain structures of relationships facilitate such deliberation. Dense cliques of individuals or organizations tend to support social processes that lead to conformity within the clique, making discussions about ideas easy and the adoption of innovations, once accepted, quick (Morris 1981; Strang and Soule 1998: 272). However, such cliques are less likely to be diverse and have information from or adopt innovations from outside that clique. In contrast, social structures characterized by weak ties between such cliques allow information and innovations to spread easily (Gould 1991; Granovetter 1973; Rude 1964). As a result, deliberation about innovations between diverse participants is most likely in a context that combines weak and strong ties.

However, weak ties that provide the new ideas may be broken or constrained within systems that are highly centralized or competitive. Indeed, highly centralized networks, also known as hierarchical networks, are dominated by a single prestigious node/organization/actor. As Ron Burt (1980) writes "A system is centralized to the extent that all relations in it involve a single actor. It has a hierarchical structure to the extent that a single actor is the direct or indirect object of all relations in it" (117). In such a network, diffusion is much more dependent on the opinion and activity of these opinion leaders than in less centralized networks.

Some organizational forms are also understood to be more innovative than others. When we turn to this topic, we find that there is contradictory information about the relationship between it and the incorporation of innovations. This is in part due to a conflation between analyses of innovativeness and analyses of openness to innovations (Strang and Soule 1998). Nevertheless, a long tradition of work in sociology has argued that formalized, centralized bureaucratic organizations have an increased tendency to reproduce themselves and avoid risky innovations (Michels 1959; Weber 1968). However, Zmud (1982) and others have found that such organizations, once they've taken the risk, are more able to adopt or implement innovations than decentralized and informal organizations (in the case of organizational innovations).

The "innovation" I'm examining here is the identity and practice of horizontalism or horizontality. In her study of recent Argentinian social movements, Marina Sitrin explains horizontalism "does not just imply a flat plane for organizing, or non-hierarchical relationships in which people no longer make decisions for others. It is a positive word that implies the use of direct democracy and the striving for consensus, processes in which everyone is heard and new relationships are created" (2006: v). Osterweil explains that horizontalism is associated with loose network of rather heterogeneous groups-including anti-authoritarian, autonomist, feminist, anarchist, and other groups and individuals-who believe that "the most important thing in the politics for a New World is how we relate to each other in making it happen” (2004: 499). Sitrin argues that horizontalidad is a new way of relating, based in affective politics and against all the implications of "isms (2006: vi)." The elements of horizontalism are of course not new. For years, social movement activists and theorists have talked about non-hierarchical approaches to organizing and direct democracy. New social movements have long argued for the importance of prefigurative forms of organizing. However, what is new is the frame of horizontalism as an identity and a strategy.

Movement identities are associated with particular strategies, and vice versa. Following Charles Tilly and Sidney Tarrow, I see these as relationally constructed. Political identities 


\section{JOURNAL OF WORLD-SYSTEMS RESEARCH}

revolve around boundaries separating 'us' from 'them'. They are constructed partly through the pattern of relationships amongst 'us' and between 'us' and 'them'. They are also constructed partly through the stories about 'us' and about 'them' and about how 'we' treat 'them' and how 'they' treat 'us' (Tilly and Tarrow 2007: 79). The emergence and transformation of such relationships and identities are thus rooted in the political histories of a particular place and time.

The increasing articulation of a horizontalist identity in Porto Alegre was tied to the popular rebellion that led to the collapse of the Argentinian government and economy in December 2001. In the months following that moment, activists involved in taking over factories, and creating popular assemblies and neighborhood infrastructure increasingly began to describe themselves as horizontalists, and their process as horizontalidad. Solidarity activists around Latin America and across the globe picked up the term and began to use it to describe their own emphases on autonomy, networked, non-hierarchical structures and prefiguration. Activists referred to movements like the Zapatistas of Mexico, the MST of Brazil and networks like People's Global Action as horizontalist. In particular, the term began to be used by activists to differentiate themselves from activists who utilized what were seen as 'old' ways of doing politics.

Since the first World Social Forum, this tension has taken place. In the following, I will use formal and informal activist documents to track the emergence and increasing prominent articulation of a horizontalist identity within the Intercontinental Youth Camps of the WSFs. I do this by analyzing movement media, blogs, and movement documents and focusing on discussions about the components within the horizontalist identity - a rejection of hierarchical forms of organization, electoral politics, political parties and an embrace of prefiguration and network structures.

Since the first WSF in Porto Alegre, the IYC has involved conflicts between activists who identified explicitly with a "horizontal" identity and those described as having a more "vertical" approach to politics (Juris 2006; Morrison 2006b). Through time, the control of the IYC has shifted back and forth between the horizontalists and those they saw as their opponents. The first IYC was a response to a shortage of affordable housing at the WSF at Porto Alegre and was coordinated by traditional Brazilian youth organizations including leftist parties such as the PT (Workers Party), the Communist Party of Brazil, the Unified Socialist Workers Party, and the Socialist Youth Union (Juris 2006; Morrison 2006b). They organized in various ways, reflecting their ideology and routine ways of operating, ways that tended to be relatively hierarchical and bureaucratic.

Shortly after the first IYC, a broader youth committee was set up, which quickly became the 2002 Camp Organizing Committee (Comitê Organizador do Acampamento: COA). This committee was comprised of two interconnected bodies: the Rio Grande do Sul Youth Committee, run mostly by the autonomous social movements; and a National Youth Committee, dominated by leftist partisan youth (Nunes 2005a: 283 in Morrison 2006b: 38). Various commissions and organizing structures were initiated; street kids and hip-hop activists worked on cultural events, while architecture students joined the Planning and Infrastructure Commission to develop environmental plans for the site, and the Communication Commission that consisted mainly of PT youth and university communications students developed community radio projects (Morrison 2006b: 42).

With these multiple hubs emerging, some activists who identified with the horizontalist identity argued that the emphasis on decentralized collaboration should become more explicit and 
intentional. As the program for the 2002 IYC began to come together, some organizers began to talk about the IYC as having a process and an identity that was different to the WSF project (Nunes 2005a: 284), and one that was experimenting with new ways of interacting, living, and organizing. When the second camp began, its participants held workshops in buildings made of biodegradable materials, ate organic food from agricultural cooperatives, and had their waste recycled by teams of volunteers (Morrison 2006b: 45). Also within the IYC in 2002 was the Intergalactika Laboratory of Global Resistance, which became a hub for groups locally and internationally who identified with principles and practices of horizontalism (Morrison 2006b: 46, Osterweil 2003). Proponents of this emerging approach, however, came into conflict with other organizers that were perceived to exhibit an "old school" approach, in particular, those activists from party organizations and student unions.

The conflict began to intensify. The COA tried to reduce the tension between proponents of the different identities. First they prevented members of the Union of Socialist Youth, the PT Youth, and the National Student's Union from putting up their own marquees, claiming both that the large membership and resources of these organizations would be overbearing for other groups of campers, and pointing to Principle 9 of the WSF Charter of Principles, which prohibited political party representation (WSF 2002). They accused the party organizations of 'having their own agendas' at the IYC that would lead to division and sectarianism. Next, the Camp Organizing Committee almost prevented some groups in the Intergalaktica space from carrying on self-organized activities since the COA wanted everybody to share the spaces (Nunes 2005b: 302-303). At the end of the 2002 WSF, the camp did not agree to a final resolution as they had the previous year, despite the efforts of many participants. Indeed, one observer argued that the participants from the leftist political parties and the participants identified with the horizontal networks barely interacted (Nunes 2005a: 286-287).

As a result of these battles, and increasing suspicion by 'horizontalists' of the motives and approaches of political parties and student unions, the majority of the IYC organizers decided that the COA would take on exclusive responsibility for logistics, registration, and the allocation of space for self-organized activities in the next Camp (Nunes 2005b: 301). Ironically, this decision placed the 'autonomous' non-partisan activists in the odd position of controlling the activities for IYC 2003 in a most "non-horizontalist” manner (Morrison 2006b: 47).

As time has passed, the IYC became increasingly associated with a 'horizontalist' identity (Nunes 2005a). The party organizations that initiated the first IYC became increasingly marginalized. By 2005, members of political parties made up less than a third of the COA (Oliveira 2005: 324-325). The camp manual for the IYC in 2005 explained that the camp was designed to "create a short-circuit in the old forms of political representation. It's a laboratory of the new political militancy seeking to make resistance an act of creation, to promote counter power" (cited in Juris 2006). There was a push to reject what were perceived as 'old' ways of doing things, in favour of what was framed as the 'new' approach of horizontalism. That same year, the IYC formally identified itself as "an innovative space for generating new forms of social, political, and cultural interaction.”

The battle between promoters of the 'new' horizontalist identity and what were seen as 'old' party activists reflected similar struggles across the forum and the global justice movement as a whole. The battle was partly a product of the global trend and partly a product of the local context (Osteweil 2004). While the IYC in Porto Alegre is partly a result of trends in the global justice movement worldwide, it also reflects the vision, capacities and dynamics of activists and 


\section{JOURNAL OF WORLD-SYSTEMS RESEARCH}

organizers who reflect the local history of Porto Alegre and the larger context of Brazilian politics (Youth Facilitation team at the World Social Forum Secretariat, 2006).

Porto Alegre is one of the wealthiest cities in Brazil, and one whose left wing political life over the past twenty years, has combined both the party orientation of the PT (Partido dos Trabalhadores) with experiments in participatory democracy. The PT was elected in 1989, after years of popular frustration with the existing parties. The newly elected government did not want to replicate the old ways of operating, especially in the post 1989 environment. In this context, participatory budgeting was introduced by the government in Porto Alegre (Biaocchi 2006). While implemented by the party, the practice was deeply influenced by the radical Freirian popular educators, neighborhood councils and progressive clergy that have long played a key role in Brazilian politics. This emphasis on dialogue, direct participation, and capacity building is clear within the IYC as it is in the WSF at large (Morrison 2006b: 29). However, despite the progressive approaches of the PT, some social movements continue to be frustrated with electoral and state-oriented politics. The push towards horizontalism that emerged at the IYC in Porto Alegre is partly a product of this frustration. Beginning in the mid 1990s, the PT has been critiqued for not following through on his promises to the poorest Brazilians, and for continuing to sign onto neoliberal trade agreements. By the time of the first WSF, increasing numbers of grassroots activists were beginning to distance themselves from the party. Some of these activists, especially the younger ones began to embrace a horizontalist identity.

Of course, the horizontalist ideal of the IYC trumpeted by organizers and writers was never fully enacted. Horizontalist organizers interviewed by Morrison critiqued the IYC in Porto Alegre for intentionally or unintentionally engaging in "vertical" practices. Nevertheless, the IYC in Porto Alegre increasingly developed an identity and strategy that its participants would refer to as horizontalist. Indeed, this became naturalized to such an extent, that by the time of the IYC in 2005 it appeared an essential and intrinsic element of the Intercontinental Youth Camps.

In 2005, after the WSF in Mumbai in 2004, the IYC returned to Porto Alegre and the horizontalist identity became increasingly articulated. A report from the Camp Organizing Committee (2005) described the IYC process in the following manner:

The political process can be characterized by ideas such as self-management, horizontality, diversity and creative resistance, experimenting and proposing alternatives that oppose capitalist and neoliberal hegemony ... The organizational process is based on a horizontal-hierarchical hybrid structure with ten commissions and the COA (Organizing Committee of the Camp) as the main organs of articulation and collective decision making. All decisions are made by consensus and the commissions have a high degree of autonomy in order to decentralize the process as much as possible. The participants of the process are individuals as well as representatives of groups, organizations and social movements, most of them Brazilian, yet without leaving aside the focus on international issues.

2005 ended up being the biggest camp to date. The 35,000 registered campers accounted for $22.6 \%$ of the total Forum population of 155,000 (IBASE 2006: 14). However, the sheer size and diversity made the horizontalist practices unwieldy. In the past, participants from each section of the camp were able to coordinate tasks, share information and communicate to new 
participants what was expected (Morrison 2006b: 30, 54). In 2005, this system was overwhelmed by the scale of the event. Many participants did not understand the way they were expected to participate and treated the space simply as accommodation. Despite attempts to keep the space as an alternative economy and society, one that reflected values of social justice; theft and the rape of some young women occurred. Nevertheless, activists reporting back on the experience continued to articulate the camp's two main organizing principals as horizontalism and self management (Gonzalez 2005). Nevertheless, the horizontalist identity and culture celebrated in Porto Alegre, was not found to the same extent at the IYC in Caracas Venezuela the following year.

\section{BLOCKED DIFFUSION OF THE HORIZONTALIST IDENTITY}

The horizontalist identity would be most likely to diffuse to new sites when local organizers in those sites had information that articulated the usefulness and attractiveness of the innovation and when those potential adopters had an opportunity to engage in deliberation about that innovation. Despite the horizontalist identity being central to the intercontinental youth camp in Porto Alegre, in Caracas, the local context and timing of the World Social Forum and the Youth Camp meant that the discussions necessary for diffusion were blocked. As a result, the IYC's identity was much more influenced by the pre-existing, dominant local models of organization and political identities.

The Intercontinental Youth Camp was organized in Caracas as part of the larger World Social Forum. The Organizing Commission of Caracas was made up of representatives of different youth organizations that hoped to create a place that was not only inexpensive housing for youth, but a forum for events and interactions it itself. The coordinator of the camp "El Che" explained, "As things stand, the youth camp will be held at La Carlotta, the military airbase in Caracas, a place that can hold the expected 26,000-35,000 people. Imagine a whole bunch of young people coming to the youth camp with a range of ideas, from anarchism to anti-militarism, and they will be camping at a military site. This could become quite interesting!” (Windisch and Price 2005)

Many participants were enthusiastic about the camp in Caracas, citing good security, access to vegetarian food, and effective organization. One Venezuelan student explained, "At night, people get together here, and have fun together. We were in the pacifist tent, and [in another there was] samba, salsa, we played drums, and danced," said Alex Reyes. "We're here to have another opportunity to get to know people... The best way to [do that] is to live with them and spend time with them,” said Jean Carlos Rosa, another member of the group (Baribeau 2006). The camp was much smaller than it had been in previous years, with the registered camping population numbering 1,200 people, well below the expected number (Morrison 2006a). There were two youth camps in Caracas. Heavy rains, the resulting mud and the distance between the WSF main site and the youth camp led the more isolated camp to become largely neglected. There were also concerns about the lack of water, light and safety at the camps. One participant, Jade compared the camp to the one in Porto Alegre, arguing that in Porto Alegre the camp was much more expansive (Jade 2006). Another camper critiqued the decision-making for being undemocratic. One French Canadian activist Pierre Marin, argued that camp decisions were hierarchical and failed to consult campers, and arguing that the camp newspaper, El 


\section{JOURNAL OF WORLD-SYSTEMS RESEARCH}

Querrequerre, was organized and largely written by people who weren't staying in the camp (Baribeau 2006). While my evidence is only partial, there were no report backs describing 'horizontalism' or using the language that had been used around the space in Porto Alegre. I believe that this lack of discussion around horizontalism in Caracas suggests that the explicit 'horizontalist' identity of Porto Alegre's IYC had not diffused to Caracas. Why not? I think that this can be explained by the way that there is no evidence of deliberation amongst local organizers about horizontalism. This lack of deliberation is due to the way that the local context was centralized around party organizations, and because of the way it was polarized between those who supported Chavez and those who opposed his regime. Deliberation was also limited because of the timing of the event-shortly before an election-which added to the polarization, and shortly after the recent success of the World Festival of Youth and Students, which had largely utilized a party-centric model of organization.

\section{Centralized Political Networks}

Letus look at the relational context of the new host city first. As elucidated earlier, past research has shown that certain types of relational contexts are more receptive to locally new ideas. Rogers (2003) noted that the relational context of a site of reception can constrain or facilitate its receptivity to innovations. One of the barriers to diffusion is a centralized political context. By centralization Rogers means the degree to which power and control in a system are concentrated in the hands of relatively few individuals. Research suggests that the more an organization or system is dominated by a few strong leaders, or the more centralized it is, the less likely it will be innovative or open to new ideas (Rogers 2003: 380, 411). This corresponds with observations that those actors less influenced by these central leaders are often more likely to innovate. Elisabeth Clemens (1997) noted in her study of the diffusion of policy innovations in $19^{\text {th }}$ century U.S., "The potential for innovation was concentrated at the peripheries of American politics, where marginalized actors mastered alternative forms and dominant institutions were less firmly established, providing opportunities for experimentation” (91-92).

Local political networks were centralized around the party organizations that either supported or opposed Chavez. As I've explained, past research has shown that the centralization of political networks can limit the possibility of deliberation by limiting the diversity of opinions participating in debates. The political networks in Caracas have historically been dominated by a small number of players, most notably, the political parties (Levine and Crisp 1999; Ellner 1999: 77; Friedman 1999). Although stable, this system left little room for emerging social forces to find expression, or new identities to be experimented with. As Levine and Crisp (1999: 129) point out, comparative work on political parties has shown how political parties often channel conflict and constrain the choices of political actors. Nevertheless, through the 1980s and 1990s there have been recurrent attempts by social movement organizations and citizen groups to adopt more participatory and decentralized approaches to decision-making (Crisp and Levine 1998, Friedman 1999). These experiments in civil society emphasized their small scale, autonomy from state control, and internal democracy (Crisp and Levine 1998: 41). In the early 1980s, neighborhood movements emerged in urban middle-class areas, and a few years later, partly as a result of the impact of transnational feminist organizing, the women's movement began to expand. There was also an attempt to develop a coordinating committee of NGO organizations of women that used 
decentralized and non-hierarchical decision-making (Friedman 1999: 365). However, the coalition did not endure, as pressure against non-partisan organizing models increased.

Particularly since Chavez was elected in 1998, party organizations have reasserted themselves as the dominant organizational form in the political field (Laako 2006). This partycentrism does not suggest that Chavez has only promoted this form of organization. In 2001, Chavez and the movements associated with him launched the Bolivarian circles, a network of loosely-knit political and social organization of workers' councils that emphasized participatory democracy and autonomy from the government. These circles have played a key role in organizing support for the government as well as resistance to the oil company executives. They are both of the state and apart from it.

Unsurprisingly, some WSF organizers and local activists feared that the WSF in Caracas would end up being controlled by the Chavez government. Others disagreed, and in the end, most participants argued that the Venezuelan context influenced the Forum in important ways (Boron 2006, Brunelle 2006, Hernandez 2006). One observer, Luis Hernández argued that this Forum was characterized by a "more markedly politician-state character". He argued that this meant that the debates were different to those at past forums, focussing more "on electoral strategies and on the resistance to the imperialism and on regional integration" (Boron 2006). He continued, saying that the Caracas WSF was nearer to an orthodox anti-imperialist project that an alter-globalization forum. He argued that the party models associated with the left of the 1970s were reborn there, and were consuming other expressions of critical thought (Hernandez 2006). Others celebrated this shift. John Hammond (2006) interviewed Edgardo Lander, a sociologist on the Venezuelan Facilitating Committee who, commented that earlier forums expressed a general feeling that social movements should be independent of unions, parties, and governments because movements are "more genuine and more expressive of the sentiments of the base." But the world has changed, he argued: "The military politics of the United States is more aggressive, the impact of free trade is felt more, and politically you can't maintain that separation” (Hammond 2006). It wasn't simply the presence of party organizations that limited the openness for horizontalism at the IYC. The Brazilian Workers Party (PT) is equally influential in the Brazilian context and Indian Communist Parties had been involved in the hosting of the WSF in Delhi.

Political parties of course, are formal, bureaucratic organizations (Michels 1959). Their structure limits the deliberation essential to the incorporation of outside political innovations. The degree to which an organization is bureaucratic is measured by formalization (Rogers 2003: 377). Formalization, or the degree to which an organization emphasizes its members' following rules and procedures, inhibits the likelihood that participants in a particular organization will discuss an outside innovation. However, if an innovation is discussed and adopted, formal organizations make implementation of a decision straightforward. The city and national government provided a great deal of support to the WSF and IYC in Caracas, as they had in Porto Alegre. Dan Morrison explains that the Venezuelan state provided sound equipment, food for volunteers, and services such as infrastructure and electricity. The state also provided building materials for tents to host the Forum activities and establish parts of the two planned World Youth Camps. The main camp was designated in a park outside of the city and bus rides were provided. If the first camp were to fill, the backup camp was designated for a city park near the main areas of WSF events. The state also organized thousands of civil servants and volunteers who managed the venues (Morrison 2006a). This was not unusual. In Porto Alegre, the city government also played a central role in organizing and supporting the WSF and the youth camp. However, the PT has a more recent 


\section{JOURNAL OF WORLD-SYSTEMS RESEARCH}

collaborative relationship with social movements like Brazil's Landless Rural Workers Movement, (MST) than Chavez' Fifth Republic Movement (MVR). The MST, while not a horizontalist organization, incorporates the popular education approach of Paulo Freire, with his emphasis on awakening the critical consciousness and sense of responsibility of all movement participants through discussion.

The MVR organizers in Caracas were less comfortable with horizontalist models of organizing. The Director General of the Intercontinental Youth Camp, Eduardo Che Mercado agreed with the critique that the organization was being done in a top down manner. "[Those who make this criticism are] totally right. We've realized, and have been learning with the people in both camps that our way of being and our way of living in Venezuela is really vertical," The forum has reflected that [working in a horizontal manner] has been very difficult for us, but it also has reflected that we have the will and the possibility to work towards it. (Baribeau 2006)" The prominent role of the state and supportive political parties that operated within a bureaucratic, hierarchical model, made the possibility of deliberation about organizational approach and incorporating the horizontal tradition of earlier IYC’s less likely.

\section{Polarized Political Context}

The second aspect of the local political context that limited the openness of the local organizers to the horizontalism of earlier IYC's were two different polarizations. The first was between the forces supporting and opposing the Chavez regime. This polarization helped to block the diffusion of horizontalism. As Marshall Ganz argues, the strategic capacity of an organization is greater if "a leadership team includes insiders and outsiders, strong and weak network ties, and access to diverse, yet salient, repertoires of collective action (Ganz 2000: 1005).” Polarization limits the diversity of participants in any deliberation, as conversations tend to be limited to one side or another of a debate. Because of the polarized nature of the political context, and the urgency around defending the Bolivarian 'revolution,' from internal and external threats, there was less openness to discussing the possibility of horizontalist ways of organizing.

Tied to the polarization around the upcoming elections was a second historical tension between parties and more horizontally organized social movements. Middle class social movements had experimented with non-hierarchical forms of organizing in Caracas in the past, partly as a critique of political parties (Crisp and Levine 1998; Ellner 1999; Friedman 1999). Indeed, there had been a rivalry between the models and identities for at least twenty years. The middle class neighborhood movement, with its emphasis on civil society, and explicit opposition to political parties had emerged in the 1970s and 1980s partly as a rejection of the centralized political arena. In return, while at various moments the parties had attempted to penetrate that movement, tensions continued between them (Crisp and Levine 1998: 43). As a result, in the polarized context of Caracas, the organizers of the forum rejected horizontalism. The IYC Camp director Che Mercado argued that "now was not the time to make changes. If I'm honest, within the forum organization, there's no horizontality. It doesn't exist. And this is a historical moment in the country, there should not be horizontality," he said, pointing out that it was an election year and that he thought that Venezuelan President Hugo Chavez needed to be reelected." He continued, "As soon as we've achieved this, we can begin to work in the evolution of this new revolutionary political process, which obviously should be horizontal and that I personally call popular power," he said. One participant at the WSF reported hearing this explanation repeatedly, 
"The priority was to defend the Bolivarian revolution. Now was not the time for risk-taking." Many had hoped that December's parliamentary elections, which, after a partial opposition boycott, gave the governing coalition 100 percent of the seats in the National Assembly, would be the turning point where Chávez supporters were given the political space to act less defensively (Baribeau 2006). In this context, open deliberation about the horizontalism was much less likely.

\section{Recent Success of World Festival of Youth and Students}

There was another reason why horizontalism was rejected by the organizers in Caracas, and that was the recent success of the World Festival of Youth and Students. Six months before the WSF opened in Caracas, the same organizing body organized a forum that was in many ways similar to the WSF. The World Festival of Youth and Students brought fifteen thousand left wing youth and students from 144 countries around the slogan "For Peace and Solidarity, We struggle against Imperialism and War." Like the WSF, the WFYS involved cultural events, speeches, and meetings between delegations of you activists from different countries. Like the WSF, the WFYS aimed to build alternatives to the current neoliberal order. The event surpassed expectations in terms of size, and was declared a success.

Like the WSF, the festival in 2005 was hosted by youth wing of the Fifth Republic Movement (JVR). Tied to the ruling party, the WFYS was not a horizontalist event. The first WFYS had been initiated by the Soviet Union in 1947, and despite some shifts since 1989, the festival is still dominated by communist parties. Coming out of the Soviet context, this model continues to be dependent on state support. The president of the Venezuela National Preparation Committee (NPC) for the WFYS reported that youth organizations in Venezuela are collaborating with the country's government to organize housing, transportation and conference facilities.

The fact that Caracas had hosted such an event so recently limited the openness of the Venezuelan organizers to the more horizontalist approach identified with the IYC. As a result, the organizers for the Intercontinental Youth Camp at the WSF were less receptive to the horizontal approaches used in past forums. This recent history hardened the boundary between those who would be most likely to identify as horizontalists within Venezuela and the organizing committee. Local anarchists critiqued the WSF process in Venezuela. They argued, "Judging from past experience (National Social Forums, events of solidarity with Venezuela, the Sixteenth World Festival for the Youth and the Students), as well as the organization and dynamics of the very same Committee for the Promotion of the Sixth World Social Forum in Caracas, we have good reasons to believe that the next World Social Forum, which will take place in Caracas, January 24 to 29, 2006, will not be the diverse, self-managed, open, independent and participatory encounter as it is claimed to be in its mission statement” (CRA 2006). Even the IYC, they argued, would not be a horizontalist space in Caracas. The recent success of the World Festival of Youth and Students made it less likely that the local organizing committee would be interested in discussing new models of organization, and adopting new political identities.

\section{CONCLUSION}

The Regional Social Forum of Western Ontario in Canada recently argued that they wanted to organize their forum "through self-management and a participatory framework.” They continued, 


\section{JOURNAL OF WORLD-SYSTEMS RESEARCH}

"We encourage participants and organizers to create a culture among us that overcomes the vertical politics of our world. ... We hope to learn from the Intercontinental Youth Camp (IYC) of the World Social Forum in reconciling the tensions between how we think and how we live, in a "practical laboratory" that will hopefully intensify this ongoing process in each of us " (2008). The Intercontinental Youth Camp lives on as model of horizontalist experimentation, and is associated with a particular political identity. As we've seen here, this horizontalist identity is not inevitably part of the social forum process, or even the IYC. Instead, the spread and use of it as a political identity is constrained by the ways that a local context allows its activists to deliberate about its meaning and use.

The horizontalist identity so central to the IYC in Porto Alegre was not adopted by Caracas activists in part because of the way that the context limited the interest and incentive of local organizers in deliberating about the new identity. The context made deliberation about horizontalism unattractive because of the way that political networks were centralized around a limited number of formal, political parties who were operating within a polarized context that hardened the boundaries between 'us' as conference organizers and 'them' (portrayed occasionally as those who were apathetic, middle class, or those who were actively opposing the Chavez regime). In addition, the recent success of the World Festival of Youth and Students in Caracas, provided the organizers with a pre-existing model of organization, the effect of which also limited the interest and incentive local organizers had to experiment with new tactics. Why does this story of failed diffusion matter? It matters for two reasons. First, it shows how local contexts can facilitate deliberation and diffusion, or block these processes. Second, the story suggests that we need to understand the way local contexts accumulate in order to construct the practices and identities in the global justice movement and transnational social movements more generally. We must consider the importance of sequence and proximity in the development of social movement repertoires and recognize that the development of the WSF will forever be altered by its time in Porto Alegre, Delhi, Caracas, Bamako, Karachi, Nairobi, and most recently in Belem.

\section{REFERENCES}

Baribeau, Simone. 2006. "Venezuelan Politics Touch Sixth World Social Forum Youth Camp.” Retrieved January 30, 2006 (www.venezuelanalysis.com).

Baiocchi, Gianpaolo. 2006. "The Citizens of Porto Alegre.” Boston Review. Retrieved March April 20, 2006 (http://bostonreview.net/BR31.2/baiocchi.html).

Boron, Attilio. 2006. “El Foro de Caracas: La Otra Mirada”, Retrieved April 20, 2006 http://www.forumsocialmundial.org.br/dinamic.php?pagina=bal_boron_2006_esp

Brunelle, Dorval. 2006. "Le Forum Social Décentralisé de Caracas: l’Amérique Latine Rentre en Scène.” Retrieved April 20, $2006 \quad$ (http:// www.forumsocialmundial.org.br/dinamic.php?pagina=bal_brunelle_2006_fr)

Burt, Ron. 1980. “Models of Network Structure” Annual Review of Sociology 6:79-141.

Camp Organizing Committee. 2005. "Report on IYC 2005 Process.” Retrieved April 20, 2006 (http://www.acampamentofsm.org/07.01.2005).

Chabot, Sean. 2000. "Transnational Diffusion and the African American Reinvention of the Gandhian Repertoire,” Mobilization 5:201-216. 
Chabot, Sean and Jan Willem Duyvendak. 2002. "Globalization and Transnational Diffusion between Social Movements: Reconceptualizing the Dissemination of the Gandhian Repertoire and the 'coming out' Routine,” Theory and Society 31: 697-740.

Clemens, Elisabeth. 1997. The People's Lobby. Chicago: University of Chicago Press.

Cohen, Joshua. 1989. "Deliberation and Democratic Legitimacy.” In The Good Polity: Normative Analysis of the State, edited by Alan Hamlin and Philip Pettits. London: Blackwell.

Comision de Relaciones Anarquistas (CRA) 2006. "About the FSA-Caracas 2006 and the venezuelan situation” Interview in La Rosa Negra (LRN-ci) 19 Jan 2006. Retrieved October 28, 2007 (http://www.ainfos.ca/06/jan/ainfos00238.html).

Crisp, Brian F. and Daniel H. Levine. 1998. "Democratizing the Democracy? Crisis and Reform in Venezuela,” Journal of Interamerican Studies and World Affairs 40:27-61.

Dryzek, John. 1990. Discursive Democracy: Politics, Policy and Political Science. New York: Cambridge University Press.

Ellner, Steve. 1999. "Obstacles to the Consolidation of the Venezuelan Neighbourhood Movement: National and Local Cleavages.” Journal of Latin American Studies 31:75-97

Fishkin, James S. 1991. Democracy and Deliberation: New Directions for Democratic Reform. New Haven, CN: Yale University Press.

Friedman, Elisabeth J. 1999. "The Effects of Transnationalism Reversed' in Venezuela: Assessing the Impact of UN Global Conferences on the Women's Movement" International Feminist Journal of Politics 1:357-381.

Ganz, Marshall. 2000. "Resources and Resourcefulness: Strategic Capacity in the Unionization of California Agriculture, 1959-1966.” American Journal of Sociology 105:1003-62.

Gonzalez, Javier. 2005. "Foro Social Mundial: “diversidad”, "revolución intersticial” y sueño anárquico” Destaque Internacional - Informes de Coyuntura - Año VII - Nos. 161-162 Buenos Aires / Madrid - Febrero, 2005. Retrieved April 20, 2006 (http://www.cubdest.org/0506/c0502fsm.html).

Gould, Roger V. 1991. "Multiple Networks and Mobilization in the Paris Commune, 1871." American Sociological Review 56:716-729.

Granovetter, Mark S. 1973. “The Strength of Weak Ties.” American Journal of Sociology 78:1360-1380.

Hammond, John. 2006. Interview, January 28, 2006.

Hernandez, Luis. 2006. "The World Social Forum of Caracas: A Balance.” Retrieved April 20, 2006

(http://www.forumsocialmundial.org.br/dinamic.php?pagina=bal_navarro_2006_esp)

IBASE (Brazilian Institute of Social and Economic Analyses). 2006. "World Social Forum: An X-Ray of Participation in the 2005 Forum: Elements for Debate: Sao Paulo, WSF International Secretariat.” Retrieved on April 20, 2006 (www.ibase.br).

Intercontinental Youth Camp 2004 Youth Assembly 2003 "Organisational Structure of Intercontinental Youth Camp.” IYC 2004 website. Retrieved November 5 (www.wsfindia.org/youthforum/structure.php).

Jade. 2006. "Polycentric World Social Forum 2006.” Blog entry retrieved April 20, 2006 (http://forumsocialmundial.blogspot.com/)

Juris, Jeffrey. 2006. "Youth and the World Social Forum” SSRC web forum on youth activism. Retrieved on April 20, 2006 (http://ya.ssrc.org/transnational/Juris/) 


\section{JOURNAL OF WORLD-SYSTEMS RESEARCH}

Katz, Elihu. 1968. Diffusion (Interpersonal Influence). In International Encyclopedia of the Social Sciences, edited by David Shils. London: Macmillan.

Laako, Hanna. 2006. "World Social Forum and the Bolivarian Revolution” Network Institute for Global Democratization. Retrieved on April 20, 2006 (http://www.nigd.org/nan/archivednews-and-notes/nigd/docs/WSFAndTheBolivarianRevolution)

Levine, Briah H. and Daniel F. Crisp. 1999. Venezuela: The Character, Crisis, and Possible Future of Democracy.” World Affairs 161: 123-65.

Michels, Robert. 1959. Political Parties: A Sociological Study of the Oligarchical Tendencies of Modern Democracy. Translated by Eden and Cedar Paul. New York: Dover.

Morris, Aldon. 1981. "Black Southern Student Sit-In Movement: An Analysis of Internal Organization.” American Sociological Review 46: 744-767.

Morrison, Dan 2006a. "WSF Caracas: Distinctive Exchanges, Familiar Challenges” COA News. Retrieved February 1, $2006 \quad$ (http://www.coanews.org/tikiread_article.php?articleId=627).

Morrison, Dan. 2006b. "The Intercontinental Youth Camp 2001-2005: Linking Open Space Activism, the World Social Forum and Imaginaries for Alternative Worlds” M.A. thesis. Dalhousie University.

Nunes, Rodrigo. 2005a. "The Intercontinental Youth Camp as the Unthought of the World." Ephemera 5:277-296.

Nunes, Rodrigo. 2005b. "Networks, Open Spaces, Horizontality: Instantiations." Ephemera 5:297-318.

Olivera, Romualdo Paz de. 2005. "Constructing the Intercontinental Youth Camp.” Ephemera 5:319-333.

Osterweil, Michal. 2003. “De-centering the Forum: Is Another Critique of the Forum Possible?” In The World Social Forum: Challenging Empires. Ed. by, Jai Sen, Anita Anand, Arturo $\begin{array}{lllll}\text { Escobar, } & \text { Peter Waterman. Retrieved } 2006\end{array}$ (http://www.choike.org/nuevo_eng/informes/1557.html).

Osterweil, Michal. 2004. "A Cultural-political Approach to Reinventing the Political." International Social Science Journal 56:495-507.

Opp, Karl-Dieter and Wolfgang Roehl. 1990. "Repression, Micromobilization, and Political Protest.” Social Forces 69:521-547.

Regional Social Forum. 2007. "Regional Social Forum” Open Space Forum. Retrieved May 5 2007

(http://www.openspaceforum.net/twiki/tikiindex.php?page=SocialForums\%3ARegionalSocialForum).

Rogers, Everett. 2003. Diffusion of Innovations, Fifth Edition. New York: Free Press.

Rude, George, F.E. 1964. The Crowd in History: A Study of Popular Disturbances in France and England, 1730-1848. New York: Wiley.

Sitrin, Marina (Ed.) 2006. Horizontalism: Voices of Popular Power in Argentina. Oakland, CA: AK Press.

Strang, David and John W. Meyer. 1993. "Institutional Conditions for Diffusion.” Theory and Society 22:487-511.

Strang, David and Sarah A. Soule 1998. "Diffusion in Organizations and Social Movements: From Hybrid Corn to Poison Pills.” Annual Review of Sociology 24:265-290.

Tilly, Charles. 2003. The Politics of Collective Violence. Cambridge: Cambridge University Press. 
Tilly, Charles and Sidney Tarrow. 2007. Contentious Politics. London: Paradigm Publisher.

Van de Ven, Andrew H. 1986. "Central Problems in the Management of Innovation." Management Science 32:590-607.

Weber, Max. 1968. "Bureaucracy”. Pp. 956-1005 in Economy and Society, edited by Guenther Roth and Claus Wittich. New York: Bedminister Press.

Windisch, Margarita and Susan Price. 2005. "Preparations Unfold for 6th World Social Forum in Venezuela” Green Left Weekly, October 31, 2005. Retrieved April 20, 2006 (http://www.venezuelanalysis.com/news.php?newsno=1803).

World Social Forum (WSF). 2002. Charter of Principles. Retrieved on April 20, 2006 (http://www.forumsocialmundial.org.br/main.php?id_menu=4_2\&cd_language=2)

Youth Facilitation Team at the World Social Forum Secretariat. 2006. "WSF International Youth Camp.” Retrieved April 20, 2006 (http://events.takingitglobal.org/11531). 